\title{
PERANCANGAN PENGENDALIAN LAMPU MENGGUNAKAN BERBASIS ARDUINO UNO DENGAN DIMMER LAMPU
}

\author{
Cecep Deni Mulyadi \\ Universitas Sangga Buana YPKP
}

\begin{abstract}
ABSTRAK
Dengan memanfaatkan teknologi microkontroller yaitu mengunakan program arduino yang dapat mengembangkan metode pengontrolan dan monitoring lampu menggunakan microkontroller pada penerapan teknologi yang akan dirancang .Aplikasi ini dapat menjadi sebuah alternatif pengontrolan dan monitoring lampu dimana alat kontrol lampu berupa pengunaan cahaya yang tepat.Perangkat tersebut dapat mengendalikan cahaya lampu yang berbeda, yaitu menggunakan arduino uno sebagai pengatur cahaya lampu. Hasil pengujian, dapat menyalakan dan memadamkan lampu menggunakan aplikasi arduino yang telah di program untuk mengatur tingkat cahaya yang tepat.
\end{abstract}

Kata Kunci: mikrokontroler, dimmer, arduino uno, pengendalian cahaya, programming

\section{PENDAHULUAN}

\section{Latar Belakang Masalah}

Perkembangan system elekronika semakin maju yang amana yang aman sudah memiliki system komputerlisasi dan komunikasi internet seperti, TV, VCD, air conditioner. Tetapi ada juga perangkat elektronik yang masih manual contohnya lampu (alat penerangan). Untuk menerangi sejumlah ruangan dan halaman rumah sudah barang tentu kita membutuhkan energy yang efektif dan efisien

Untuk itu, dengan memanfaatkan teknologi yang ada microkontroller, penulis di sini ingin mengembangkan metode pengontrolan dan monitoring lampu menggunakan yang terdapat pada berbasis kontrol pada penerapan teknologi yang akan dirancang penulis.Aplikasi ini dapat menjadi sebuah alternatif pengontrolan dan monitoring lampu dimana alat kontrol lampu berupa pengunaan cahaya yang tepat .

Dari uraian latar belakang di atas, maka penulis mencoba membuat alat "Perancangan Pengendalian Lampu Menggunakan Berbasis Arduino Uno dengan dimmer lampu " dimana fungsi untuk pengaturan cahaya yang di perlukan.

\section{Rumusan Masalah}

Berdasarkan uraian latar belakang diatas, permasalahan dalam perancangan ini adalah merancang sebuah alat otomatisasi lampu yang mana mikrokontroler dengan mengunakn ardunino mengunakan dimmer lampu.

\section{Batasan Masalah}

Batasan masalah dalam perancangan ini antara lain:

- Perangkat ini hanya menggunakan komponen elektronik 
- Aplikasi yang digunakan arduino uno

- Tidak membahas perbandingan daya.

\section{Tujuan Penelitian}

Tujuan yang ingin dicapai dalam pembuatan alat pengendalian lampu di dalam rumah menggunakan Adruino Uno adalah:

- Efiesiensi waktu dan daya listrik.

- Meminimalisir pembiayaan listrik yang berlebihan.

- Mengurangi resiko konsleting listrik, dengan fitu notifikasi jika lampu putus.

\section{LANDASAN TEORI}

\section{Penjelasan atau pendahuluan}

\section{diming 230 ac dengan arduino}

Perangkat yang berjalan pada tegangan DC biasanya dikontrol dengan mengubah logika pada pin GPIO untuk beralih kontrol atau oleh PWM untuk kontrol operasional. Untuk kontrol operasional atas peralatan AC seperti mengendalikan kecepatan kipas atau meredupkan bola lampu, elektronika daya masuk ke dalam gambar.

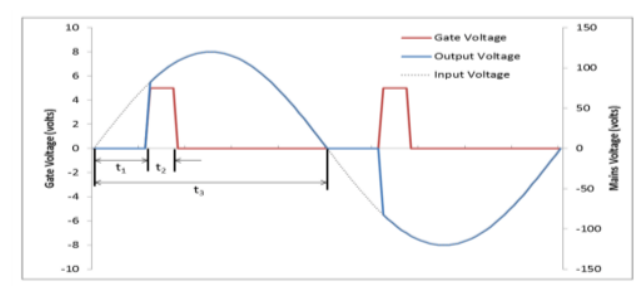

Gambar 1. Gelombang arus AC
Proyek ini adalah demonstrasi pengendalian operasional peralatan AC menggunakan deteksi persimpangan tegangan nol.

\section{Tujuan dari diming 230 ac dengan arduino}

Saya akan langsung ke titik. Cara yang tepat untuk mengontrol peredupan $230 \mathrm{v}$ $\mathrm{AC}$, adalah melalui kontrol fase dengan Triac: Triac kemudian sepenuhnya dibuka, tetapi hanya selama bagian dari gelombang $\mathrm{AC}$ sinus.

Orang bisa membiarkan Arduino hanya membuka Triac untuk sejumlah mikrodetik, tetapi itu memiliki masalah bahwa itu tidak dapat diprediksi selama bagian apa dari gelombang sinus triac terbuka dan oleh karena itu tingkat peredupan tidak dapat diprediksi. Seseorang membutuhkan titik referensi dalam gelombang sinus.

Untuk itu detektor zero crossing diperlukan. Ini adalah sirkuit yang memberitahu Arduino (atau pengendali mikro lain) ketika gelombang sinus berjalan melalui nol dan karena itu memberikan titik yang ditentukan pada gelombang sinus itu.

Membuka Triac untuk sejumlah penundaan mikrodetik mulai dari zero crossing karena itu memberikan tingkat peredupan yang dapat diprediksi. Disini menemukan dua cara sehingga dimm bola 
lampu 230V menggunakan Arduino. Keduanya menggunakan triac tetapi perbedaan utamanya adalah bagaimana Arduino harus memahami deteksi silang nol dari AC. Metode ini disebut kontrol fase AC. Ini adalah metode yang digunakan dalam banyak dimmer cahaya dan pemanas dan sirkuit kontrol daya motor. Untuk pemahaman yang lebih baik kami akan menyebutkan cara pertama cara perangkat lunak dan cara analog kedua.

\section{Cara kerja pada diming 230 ac dengan arduino}

Sirkuit deteksi zero-crossing menyediakan pulsa 5v setiap kali sinyal ac melintasi nol volt. Kami mendeteksi ini dengan Arduino dan memanfaatkan interupsi ke waktu sirkuit pemicu tepat dalam sinkronisasi dengan peristiwa zero-crossing ini. Metode untuk kontrol daya ditunjukkan pada diagram di bawah ini.

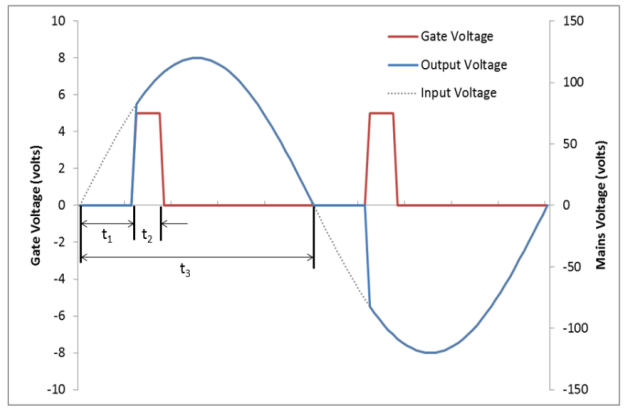

Gambar 2. Gelombang arus AC (alternating current) menggunakan triac

Setelah nol persimpangan terdeteksi, triac tetap off untuk jumlah waktu yang terkendali (t1). Semakin panjang waktu ini, semakin sedikit daya yang diterima sirkuit ac. Setelah "off-time", t1 telah berlalu, mikrokontroler menyalakan triac dengan menerapkan tegangan ke gerbang (ditampilkan dalam warna merah). Setelah dinyalakan, triac akan tetap menyala bahkan setelah tegangan gerbang dilepas. Ini akan mati jika tegangan gerbang nol saat berikutnya gelombang ac melintasi nol. Karena itu, kita tidak perlu berhati-hati untuk mematikan triac ketika sinyal ac melintasi nol lagi. Yang perlu kita lakukan adalah memastikan bahwa triac dimatikan dalam periode $1 / 2$ gelombang ( $\mathrm{t} 3$ ). Durasi pulsa gerbang (t2) ditentukan oleh persyaratan minimum dari traic. Jika pulsa ini terlalu pendek, traik tidak akan menyala Setelah penyilangan nol kedua terjadi, kutu tidak ada tegangan di gerbang, triac tetap mati hingga dipicu lagi dalam siklus $1 / 2$ berikutnya. Hasil bersihnya di sini adalah bahwa kita "memotong" bagian dari gelombang yang menghasilkan daya ratarata lebih rendah. Ini pada dasarnya adalah bagaimana seseorang menyelesaikan kontrol "PWM" dari gelombang AC.

Kami akan menggunakan interupsi dan timer arduino untuk secara tepat mengontrol waktu dari gerbang triac. Sinyal AC adalah $50 \mathrm{~Hz}$. Apa artinya ini adalah bahwa sinyal AC melintasi nol, mencapai tegangan puncak positif, melintasi nol, mencapai tegangan puncak negatif dan kembali ke nol 50 kali setiap detik. Periode (lama waktu yang diperlukan) adalah 1/50 atau 0,02 detik (20 
milidetik). Setengah siklus (waktu antara dua zero-crossing) terjadi dalam 10 milidetik. Ini adalah t3 pada gambar di atas.
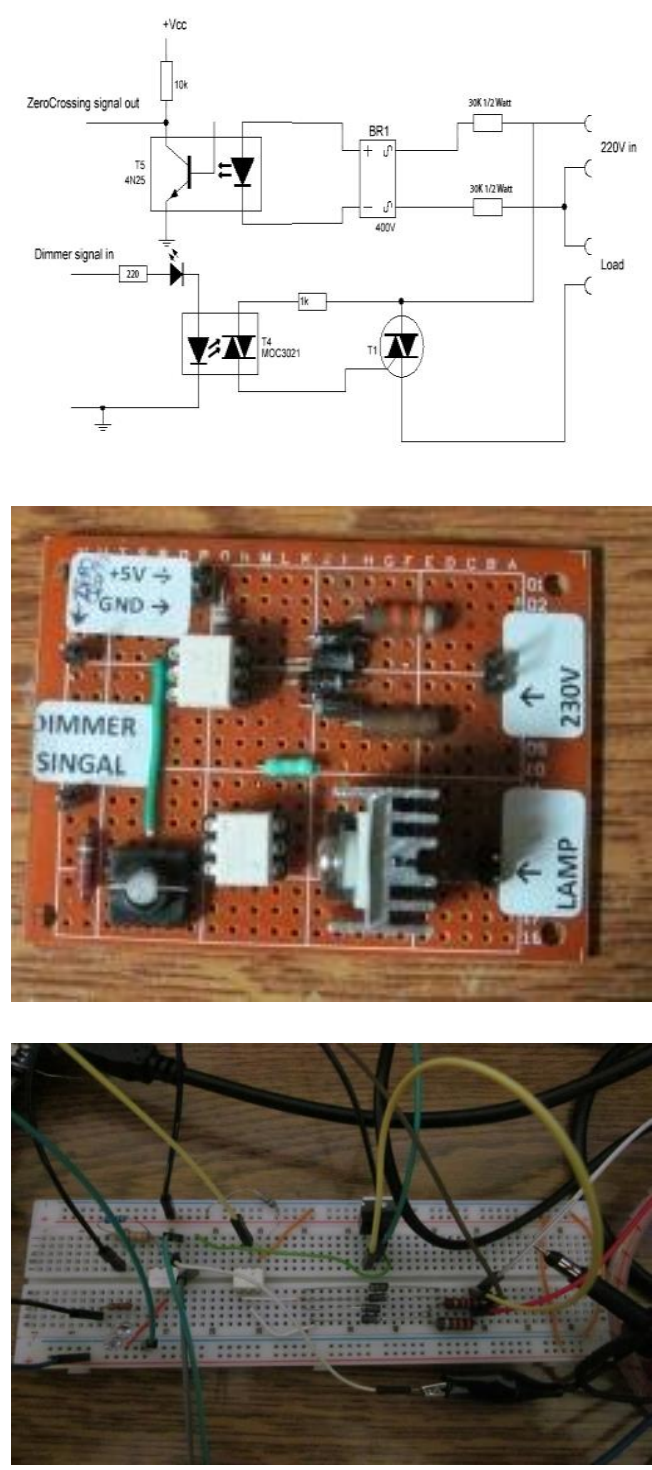

Gambar 3. Rangkaian dimmer lampu

Sirkuit yang digambarkan di sini tidak hanya itu. Tegangan listrik 220Volt dipimpin melalui dua resistor $30 \mathrm{k}$ ke penyearah jembatan yang memberikan sinyal fase ganda yang disearahkan ke 4N25 opto-coupler. LED dalam optocoupler ini menjadi rendah dengan frekuensi $100 \mathrm{~Hz}$ dan sinyal pada kolektor akan tinggi dengan frekuensi $100 \mathrm{~Hz}$, sejalan dengan gelombang sinusoid pada jaringan listrik. Sinyal 4N25 diumpankan ke pin interupsi di Arduino (atau mikroprosesor lain). Interupsi rutin memberi sinyal panjang spesifik ke salah satu pin I / O. Sinyal pin I / O kembali ke sirkuit kami dan membuka LED dan MOC3021, yang memicu sebentar OptoThyristor. LED seri dengan MOC3021 menunjukkan jika ada arus yang melewati MOC3021. Pikiran Anda bahwa dalam operasi peredupan cahaya itu tidak akan sangat terlihat karena sangat singkat. Jika Anda memilih untuk menggunakan sakelar triac untuk penggunaan berkelanjutan, LED akan menyala dengan jelas.

Anda dapat memodifikasi sirkuit untuk mengendalikan motor juga. Ini terdiri dari resistor dan kapasitor tambahan. Gerbang saat ini di bawah $15 \mathrm{~mA}$. Jika Anda menggunakan triac yang kurang sensitif untuk mengontrol beban induktif, kurangi resistor dari $2.4 \mathrm{k} \Omega$ menjadi $1.2 \mathrm{k} \Omega$, sediakan lebih banyak arus untuk menggerakkan triac dan meningkatkan kapasitor hingga 200nF. Sirkuit snubber ini ada untuk melindungi triac dari tegangan tinggi yang dihasilkan dari beban induktif. Umpan balik dapat menyebabkan beberapa masalah untuk beban noninduktif. Kebocoran kecil bisa cukup signifikan untuk menyalakan beban kecil (misalnya lampu). 

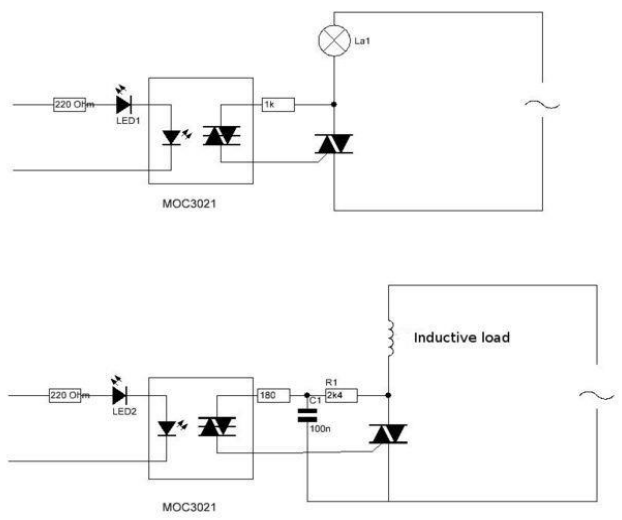

Gambar 4. Proses Mengaktifkan Triac

Yang perlu dilakukan oleh perangkat lunak adalah mendeteksi zero crossing, dan kemudian menunggu sejumlah waktu yang ditetapkan pada sinuswave tersebut untuk mengaktifkan TRIAC.

Di Eropa kita punya $50 \mathrm{~Hz} 50 \mathrm{~Hz}$ adalah 50 gelombang per detik.Setiap gelombang sinus membutuhkan waktu $1000 \mathrm{~ms} / 50=$ 20ms (milidetik).

Karena ada 2 sinus dalam gelombang yang berarti bahwa setelah setiap deteksi nol ada periode $10 \mathrm{~ms}$ yang dapat kita atur. T3 ini pada diagram.

Karena kami menggunakan TRIAC, apa yang perlu dilakukan oleh perangkat lunak adalah menunggu titik nol pada sinuscurve, catat itu dan kemudian tunggulah jumlah waktu yang ditentukan dalam jangka waktu 10ms untuk mengirimkan pulsa ke TRIAC.

Jika mengirimkan pulsa itu pada $5 \mathrm{~ms}$, lampu hanya akan terbakar setengah daya.

Kami akan menggunakan interrupt untuk memberi tahu program bahwa ada zero crossing. Setelah zero crossing dideteksi, program perlu menunggu waktu yang ditentukan dan kemudian mengaktifkan TRIAC.

\section{Fungsi Komponen Diperlukan}

- Arduino UNO

Arduino adalah sebuah kit elektronik open source yang dirancang khusus untuk memudahkan bagi para seniman, desainer, dan siapapun yang tertarik dalam menciptakan objek atau mengembangkan perangkat elektronik yang dapat berinteraksi dengan bermacam-macam sensor dan pengendali.

- LCD 16x2

Menampilkan hasil tegangan atau arus yang ada pada suatu rangkiaan

- EL 3021

Komponen ini merupakan opto isolator yang digunakan sebagai antar muka (interface) antara peralatan dengan menggunakan tegangan DC (seperti mikrokontroler, PC), dengan peralatan yang menggunakan tegangan AC (lampu, motor listrik)

$\cdot 4 \mathrm{~N} 25$

Optocoupler adalah komponen elektronika yang berfungsi sebagai penghubung berdasarkan cahaya optik. Pada dasarnya Optocoupler terdiri dari 2 bagian utama yaitu Transmitter yang berfungsi sebagai pengirim cahaya optik dan Receiver yang 
berfungsi sebagai pendeteksi sumber cahaya.

\section{- Saklar ON-OFF}

Untuk menghubungkan dan memutuskan arus atau tegangan

- Pengatur tegangan -7805

Untuk mengatur tegangan agar tidak berlebih yang telah di tentukan

- BT136

TRIAC adalah perangkat semikonduktor berterminal tiga yang berfungsi sebagai pengendali arus listrik. Nama TRIAC ini merupakan singkatan dari TRIode for Alternating Current (Trioda untuk arus bolak balik). Sama seperti SCR, TRIAC juga tergolong sebagai Thyristor yang berfungsi sebagai pengendali atau Switching.

- Kawat untuk membawa 2A, 230v AC

Kabel penghantar arus listrik

-12-0, 1 Amp Transformer

Trapo penurun tegangan dari 220 jadi 12 volt

- Dua pin steker.

- Pemegang bohlam

Dudukan untuk lampu

- 1N4007 dioda

Merubah arus AC menjadi arus DC

- Blok Terminal: PBT-2
Blok terminal adalah sekumpulan dua atau lebih titik sambungan sekrup yang sama. Anda dapat menghubungkan kabel pada titik-titik ini. Strip terminal menggabungkan banyak blok serupa dalam satu perangkat. Dalam sebuah strip, blok-blok tersebut terisolasi satu sama lain.

- 6-pin IC basis-2 buah

Dudukan IC 6 kaki

- Resistor-10k, 3k3, 330 dan 120 ohm

Penghambat arus dan tegangan

- Bread Board untuk koneksi

Unutk merangkai suatu rangkai tanpa di patenkan tapi di ujicoba dulu baru setelah berhasil bias di patenkan pada papan pcb.

\section{TAHAPAN PERANCANGAN}

\section{Flowchart Perancangan}

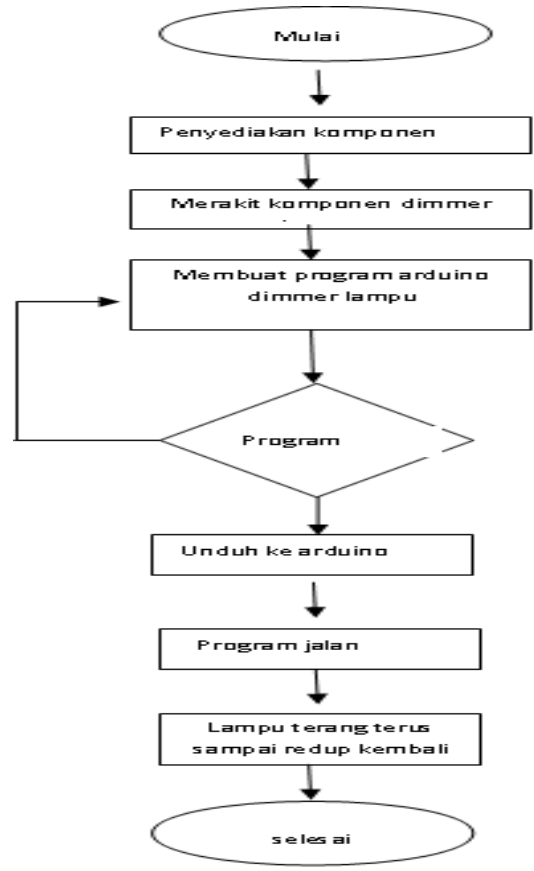

Gambar. 5 flow chart penelitian 


\section{Program pada arduino}

Setelah kita rancangan komponen yang di perlukan maka ,selanjutnya mengunakan program arduino dengan program di bawah ini.

const int triacPulse $=10$;

int $\mathrm{x}$;

int diming $=1$;

int dimtime;

void setup()\{

Serial.begin(9600);

Serial.println("test....");

pinMode(2, INPUT);

//digitalWrite(2,HIGH);

pinMode(triacPulse, OUTPUT);

$\mathrm{x}=\operatorname{digitalRead}(2)$;

Serial.println(x);

attachInterrupt $(0$, acon,FALLING); $\}$

void $\operatorname{loop}()$

$\{/ / \mathrm{x}=\operatorname{digitalRead}(2) ;$

// Serial.println(x);

//attachInterrupt(0,acon,FALLING);

//attachInterrupt( 0 ,acon,RISING);

for (int $\mathrm{i}=0 ; \mathrm{i}<=120 ; \mathrm{i}++)\{$

diming $=\mathrm{i}$;

delay(200);

Serial.println(diming);

void $\operatorname{acon}()\{$

dimtime $=(75 *$ diming $) ;$

delayMicroseconds(dimtime);

digitalWrite(triacPulse,HIGH);

delayMicroseconds(5);

digitalWrite(triacPulse,LOW);

// Serial.println("test...."); \}

\section{HASIL PERANCANGAN}

Hasil percobaan pakai diming ac voltage

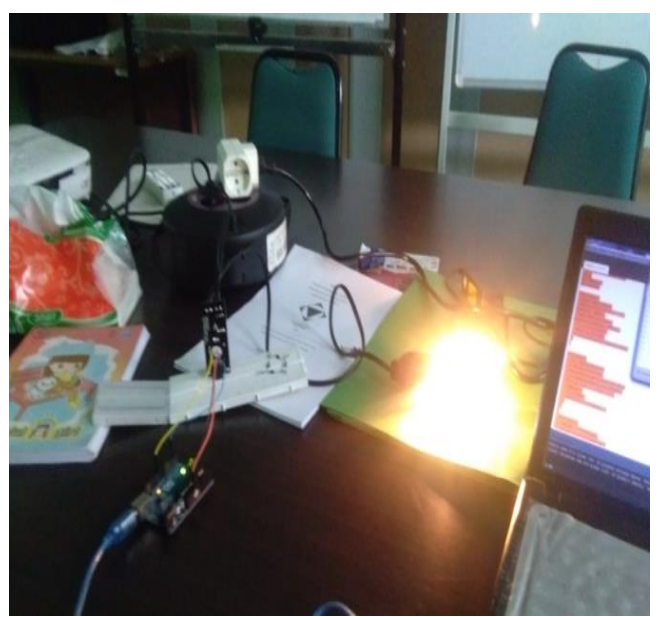

Gambar 6. Penyalaan 80-100 \%

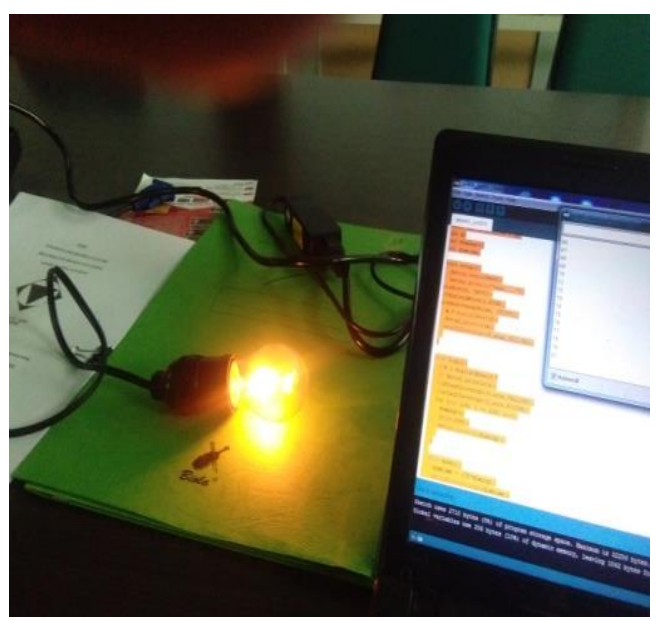

Gambar 7. Penyalaan pada 50-70\%

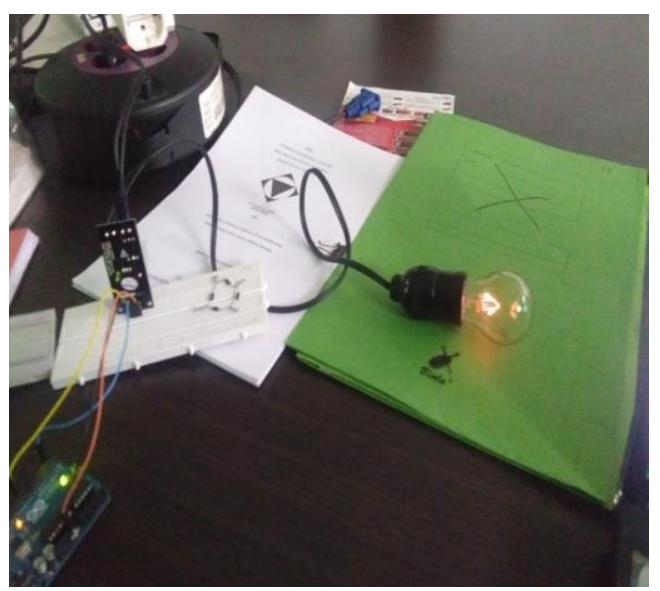

Gambar 8. Penyalaan 20-30 \% 


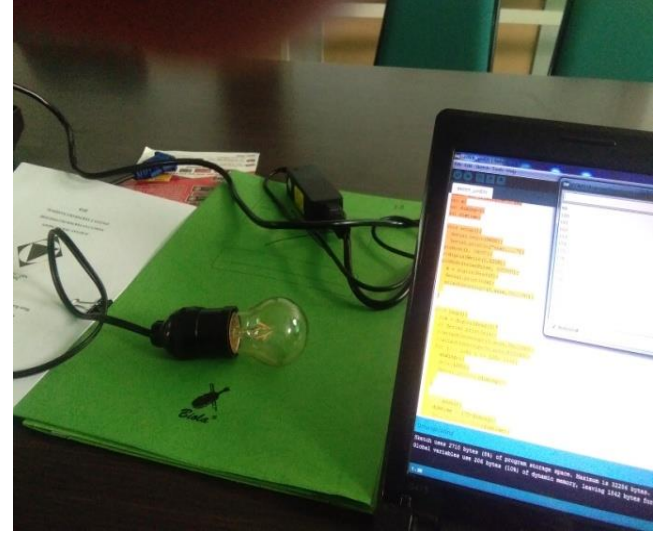

Gambar 9. Penyalaan pada 5-10\% 6,5

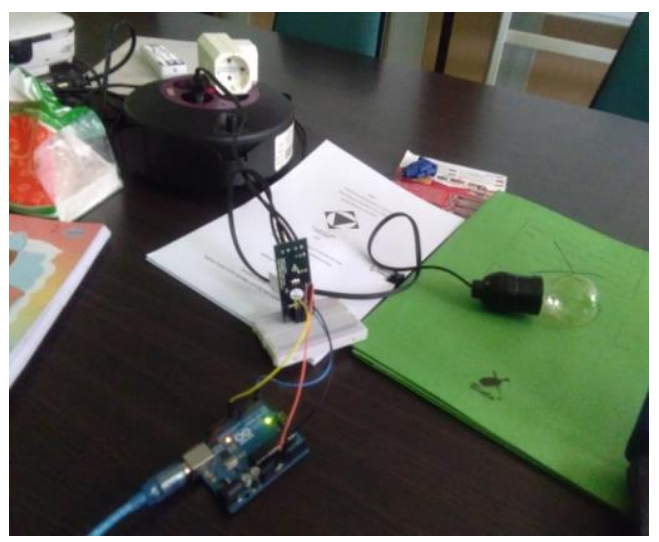

Gambar 10. Penyalaan pada $0 \%$

\section{KESIMPULAN}

Triac bisa membuat lampu menyala atau redup dengan mengaturnya ,yaitu bias kita buat dengan memilih jumlah 120 langkah secara acak. Itu berarti bahwa setiap langkah adalah $10 \mathrm{~ms} / 120=10000 \mathrm{us} / 120$ = 75us (sebenarnya 78). Total dimtime kemudian dihitung dari 75x (1 hingga 120). Jumlah antara 1-120, yang menentukan tingkat peredupan, kami menetapkan ke bilangan bulat variabel 'peredupan'.

Kenaikan dan penurunan tegangan dalam arah alternatif secara grafis ditunjukkan dengan tanda negatif tegangan dan kurva tegangan. Titik pada kurva tegangan di mana itu bergantian arah disebut persimpangan tegangan nol. Output dari optoisolator kemudian dapat diteruskan ke mikrokontroler untuk menunjukkan penyimpangan tegangan nol untuk itu. TRIAC (Triode untuk AC) umumnya digunakan untuk kontrol daya dan aplikasi switching. TRIAC dapat menjadi kontrol pakan menggunakan optocoupler yang akan didorong oleh pin mikrokontroler.

Proyek ini dibangun berdasarkan Arduino UNO dan 4N25 optoisolator dengan penyearah jembatan penuh digunakan untuk deteksi persimpangan tegangan nol. The 3021 optocoupler dan TRIAC digunakan untuk memotong tegangan $\mathrm{AC}$ ke beban. Tugas deteksi kebocoran tegangan nol dan peralihan 3021 IC dikendalikan secara terprogram oleh Arduino. Sketsa Arduino ditulis pada Arduino IDE dan menggunakan AVR Dude.

Sirkuit deteksi zero-crossing menyediakan pulsa 5v setiap kali sinyal ac melintasi nol volt. Kami mendeteksi ini dengan Arduino dan memanfaatkan interupsi ke waktu sirkuit pemicu tepat dalam sinkronisasi dengan peristiwa zero-crossing ini.

Oleh perangkat lunak mendeteksi zero crossing, dan kemudian menunggu sejumlah waktu yang ditetapkan pada sinuswave tersebut untuk mengaktifkan TRIAC. 


\section{DAFTAR PUSTAKA}

Daryanto. 2011. Ketrampilan Kejuruan Teknik Elektronika. Bandung: PT Sarana Tutorial Nurani Sejahtera

M. Syahwil. 2013. Panduan Mudah

Simulasi \& Praktek Mikrokontroler Arduino. Yogyakarta: Andi

Dodit S., dan Rina Agustina. 2012. Pemrograman Aplikasi Arduino. Yogyakarta: Mediakom

Dian Artanto. 2012. Interaksi Arduino dan Labview. Jakarta: PT Elex Media Komputindo
Immanuel, Alpha. 2012. Pembuatan Aplikasi Pengontrol Robot Berbasis Android.

Anonim. Perancangan Sistem Kontrol dan Monitoring Lampu Dengan PC Berbasis Mikrokontroler. STMIK Asia Malang

Anonim. 1999. Penerapan Konsep Dasar Listrik dan Elektronika I dan II. Makalah tidak diterbitkan

Dan Lajanto. 2013. Sistem Kendali Umpan Balik Pada Lampu Berbasis Short Message Service (SMS). Jurnal, Pontianak: Fakultas Teknik, Universitas Tanjungpura 